\title{
Consumption and ingestive behaviour of lambs fed varying levels of babassu mesocarp bran
}

\section{Farelo do mesocarpo do babaçu na alimentação de borregas: Consumo e comportamento ingestivo}

\author{
Carolina Moreira Araújo ${ }^{1 *}$; Karla Alves Oliveira²; Gilberto de Lima Macedo \\ Junior $^{3}$; Jhone Tallison Lira de Sousa ${ }^{4}$; Luciano Fernandes Sousa ${ }^{5}$
}

\section{Highlights:}

Voluntary consumption increased linearly with increased babassu mesocarp bran intake.

Water consumption was not influenced by inclusion of babassu mesocarp bran in diets of sheep.

Rumination efficiency was reduced by inclusion of babassu mesocarp bran in diets of sheep.

\begin{abstract}
Voluntary consumption (VolC) and ingestive behaviour (IB) of lambs fed diets containing different percentages $(0.0 ; 7.5 ; 15.0$ and $22.5 \%)$ of babassu mesocarp bran (I-BMB) were evaluated. The trial was at the Federal University of Tocantins, Campus de Araguaína-TO. Twenty lambs were evaluated using a completely randomized design, and five replications were performed. VolC data was obtained by measuring total volumes of both food supplied and food remaining after feeding. IB was evaluated throughout two, non-consecutive 24 -h periods, with observations were recorded every five minutes that described the following behavioural variables: resting (REST), rumination (RUM), intake (INT) and chewing (CHEW). The particle size was also measured using a Penn State particle separator. All VolC parameters (dry matter intake, DMI; crude protein intake, CPI; neutral detergent fibre intake, NDFI; and acid detergent fibre intake, ADFI) increased linearly with I-BMB intake. I-BMB consumption did not interfere with water intake, nor did it affect I-BMB did not affect the duration of DMI, NDFI and ADFI. However, linear increases of rumination and chewing activities associated with DMI, NDFI and ADFI were observed as I-BMB levels increased. In summary, effects of inclusion I-BMB in diets of lambs included increased voluntary consumption, and reduced rumination and chewing, but not ingestion, efficiency. When economically favorable, these data suggest that inclusion of up to $22.5 \%$ I-BMB within balanced diets should be applied.
\end{abstract}

Key words: Sheep. Particle. Rumination. By-products.

\section{Resumo}

Avaliou-se o consumo voluntário $(\mathrm{CVol})$ e o comportamento ingestivo $(\mathrm{CI})$ de borregas alimentadas com rações contendo diferentes inclusões de farelo do mesocarpo do babaçu (I-FMB) $(0,0 ; 7,5 ; 15,0$ e

1 M.e em Produção Animal, Universidade Federal de Uberlândia, UFU, Uberlândia, MG, Brasil. E-mail: carolina.am@hotmail.com

2 Discente do Curso de Doutorado do Programa de Pós-Graduação em Zootecnia, Universidade Estadual Paulista, UNESP, Jaboticabal, SP, Brasil. E-mail: karla.alves.oliveira@hotmail.com

3 Prof. Dr., UFU, Uberlândia, MG, Brasil. E-mail: gilbertomacedojr@gmail.com

4 Dr. em Ciência Animal Tropical, Universidade Federal do Tocantins, UFT, Araguaína, TO, Brasil. E-mail: jhonelira@hotmail.com

5 Prof. Dr., UFT, Araguaína, TO, Brasil. E-mail: luciano.sousa@mail.uft.edu.br

${ }^{*}$ Author for correspondence 
$22,5 \%$ ). O local do ensaio foi a ovinocaprinocultura da Universidade Federal do Tocantins, Campus de Araguaína-TO. Foram utilizadas 20 borregas distribuídas em delineamento inteiramente casualisado, com cinco repetições. O CVol foi realizado pela mensuração do total de alimento fornecido e das sobras. Já o CI foi avaliado em dois períodos de 24 horas em dias não consecutivos, com observações de cinco em cinco minutos sendo as variáveis comportamentais: ócio $(\mathrm{O})$, ruminação $(\mathrm{R})$, ingestão $(\mathrm{I})$ e mastigação (M). Mensurou-se também o tamanho de partícula com separador de partículas modelo Penn State. Foi observado aumento linear crescente com a I-FMB para todos os parâmetros de CVol estudados (consumo de matéria seca - CMS, consumo de proteína bruta - CPB, consumo de fibra em detergente neutro - CFND e consumo de fibra em detergente ácido - CFDA) em todas as unidades ( $g$ dia $^{-1}$ animal ${ }^{-1}, \%$ do peso vivo (PV), $\left.\mathrm{g} \mathrm{kg}^{-0,75}\right)$. A I-FMB não interferiu na ingestão de água de borregas. A I-FMB não afetou o tempo em ingestão por CMS, CFDN e CFDA. No entanto, a I-FMB aumentou linearmente as atividades ruminação e mastigação em função do CMS, CFDN e CFDA. A I-FMB na dieta de borregas aumenta o consumo voluntário de ovinos e influência de forma negativa na eficiência de ruminação e mastigação, sem prejudicar eficiência de ingestão. Quando economicamente favorável recomenda-se a inclusão de até $22,5 \%$ de FMB em dietas balanceadas.

Palavras-chave: Ovinos. Partícula. Ruminação. Subprodutos.

\section{Introduction}

Due to its climatic diversity and territorial extension, Brazil has great potential to produce various foods which generate processing residues. The vast majority of types of feed currently used are based on corn and soybeans, which are considered standard products used in the formulation of both ruminant and non-ruminant animal diets. However, the high cost of these diet staples has the potential to make production impossible, especially within regions in which they are scarce or non-existent (Abdalla, Silva, Godoi, Carmo, \& Eduardo, 2008). In this context, investigative efforts to identify lowcost, alternative foods capable of either partially or completely replacing conventional concentrated foods have been expanded (Sousa, Macedo, Santos, Silva, \& Borges, 2014).

Babaçu is a name that has been given to several types of palm trees that grow in the North and Northeast of Brazil. The palm trees produce a fruit known as babassu coconut, which has been used as a source of human and animal nutrition (Porro, 2019). In the industrialization of babassu, byproducts with nutritional potential are generated, and the possibility that they may be used in animal feed exists. This potential particularly applies to the supplementation of ruminant feed, since by- products contain large quantities of fibrous material (Miotto et al., 2012; Sousa et al., 2014).

Assessment of the voluntary consumption (VolC) and ingestive behaviour (IB) of species are of great importance in the evaluation of animal diet types, since they provide knowledge need to adequately modulate food management, and maximize productive performance (Cardoso et al., 2006). Characteristics of food such as particle size and neutral detergent fibre (NDF) content can affect animal behaviour, which can trigger digestive disorders and, subsequently, decrease production levels. Therefore, observing the natural behaviour of animals is a key parameter that must be evaluated when effects of new diets are assessed. Thus, the objective of the present study was to evaluate levels of consumption and the ingestive behaviour of lambs fed diets containing different percentages $(0.0 ; 7.5$; 15.0 and $22.5 \%$ ) of babassu mesocarp bran.

\section{Material and Methods}

The experiment was carried out at the Federal University of Tocantins, in the sector of Ovinocaprinoculture, at the School of Veterinary Medicine and Animal Science - Araguaína, from September 29 to October 15, 2013. The study was 
carried out in accordance with statements of the Committee of Ethics regarding use of animals at the Federal University of Tocantins (CEUA-UFT) and the protocol was approved by the Ethics Committee (protocol number 13101.000732/2013-04).

Twenty lambs were used with an average live weight of $23 \pm 3.2 \mathrm{~kg}$. Lambs were weighed at the beginning of the adaptation period. The lambs were previously dewormed and housed in metabolism testing cages with drinking fountains, feeders and devices suitable for collecting urine and faeces. Diets provided were balanced according to National Research Council [NRC] (2007), and contained four different percentages of babassu mesocarp bran (BMB), 0.0, 7.5, 15.0 and 22.5\%. Table 1 indicates BMB compositions of diets.

Table 1

Bromatological composition of babassu mesocarp bran (BMB)

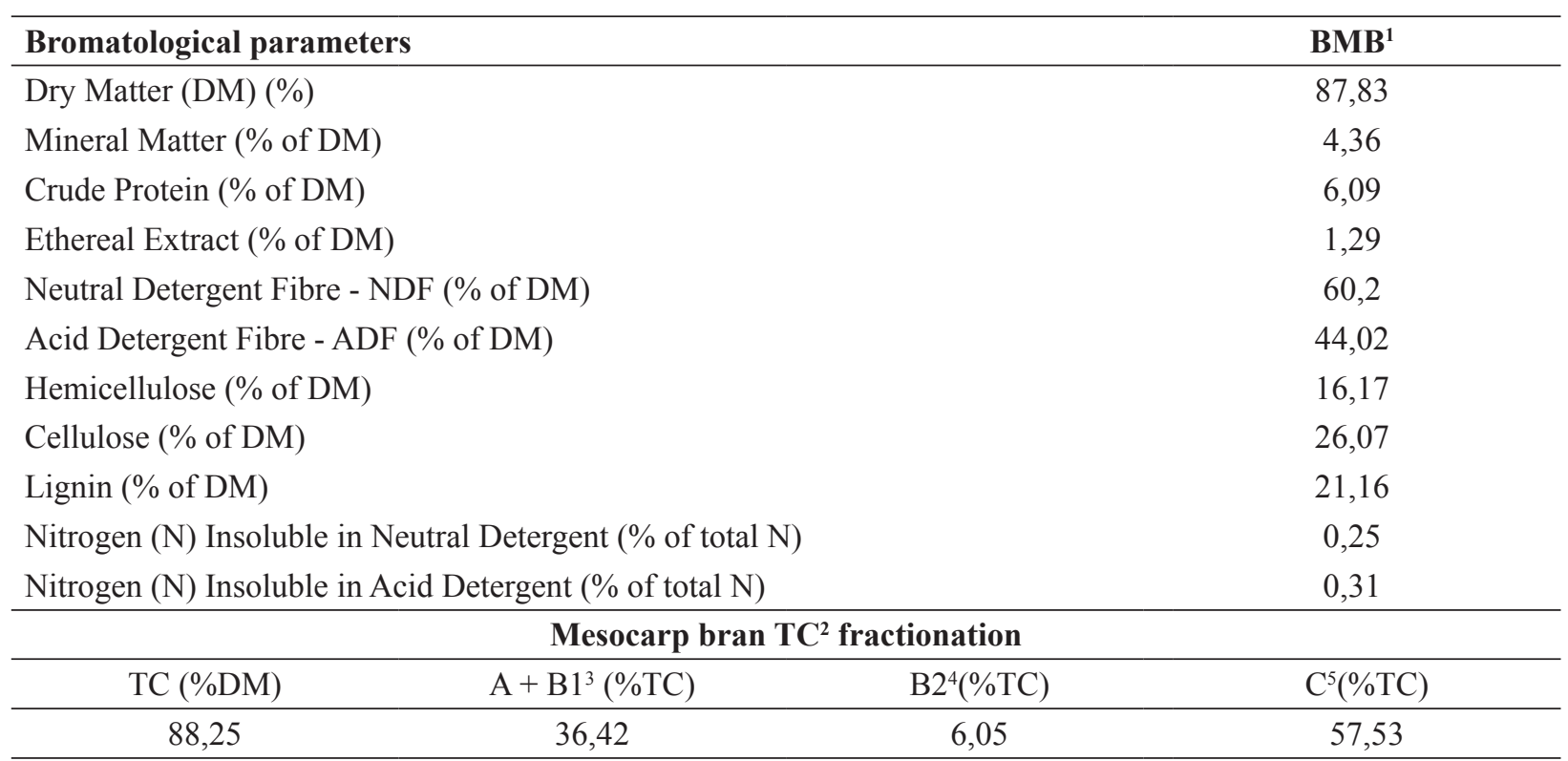

Abbreviations: ${ }^{1} \mathrm{BMB}$, babassu mesocarp bran; ${ }^{2} \mathrm{TC}$, total carbohydrates; ${ }^{3} \mathrm{~A}+\mathrm{B} 1$ = Organic acids, soluble sugars and starch; ${ }^{4} \mathrm{~B} 2$ $=$ available $\mathrm{NDF} ;{ }^{5} \mathrm{C}=\mathrm{NDF}$ unavailable.

Diets were isonitrogenated, isoenergetic and contained equal levels of neutral detergent fibre (NDF). Animals were provided a 15 days adaptation period to adjust to both diets and cages. The diets were composed of corn bran, soy bran, dicalcium phosphate, limestone, species-specific mineral salt, Napier grass silage and BMB (Table 2). 
Table 2

Percentage composition of ingredients and bromatology of diets with different levels of inclusion of babassu mesocarp bran (I-BMB)

\begin{tabular}{lcccc}
\hline \multirow{2}{*}{ Ingredients } & \multicolumn{4}{c}{ Percentage of babassu mesocarp bran (I-BMB) in feed } \\
\cline { 2 - 5 } & 0,0 & 7,5 & 15,0 & 22,5 \\
\hline Napier silage (\%) & 53,34 & 47,13 & 40,96 & 34,78 \\
BMB (\%) & 0,00 & 7,50 & 15,00 & 22,50 \\
Corn (\%) & 25,63 & 24,32 & 22,98 & 21,66 \\
Soybean meal (\%) & 16,03 & 15,91 & 15,79 & 15,69 \\
Phosphate (\%) & 0,54 & 0,69 & 0,84 & 0,96 \\
Mineral salt (\%) & 3,00 & 3,00 & 3,00 & 3,00 \\
Dolomitic limestone (\%) & 1,46 & 1,45 & 1,43 & 1,41 \\
\hline & & Bromatological composition & \\
\hline DM (\%) & 59,16 & 62,60 & 66,05 & 69,50 \\
CP (\%) & 12,00 & 12,00 & 12,00 & 60,00 \\
TDN (\%) & 60,00 & 60,00 & 60,00 & 41,25 \\
NDF (\%) & 41,07 & 41,13 & 41,19 & \\
\hline
\end{tabular}

Abbreviations: FMB, babassu mesocarp bran; MS, dry matter; PB, crude protein; TDT, total digestive nutrients; NDF, neutral detergent fibre.

Animals were provided two meals daily (8:00 am and 4:00 pm), and the first meal consisted of $40 \%$ of the daily volume provided. Offered rations and leftovers were collected and weighed daily. Subsequently, feed samples composed of animal waste and leftovers and another composed of rations provided throughout the five-d collection period were obtained. Afterward, leftover samples, together with the ration samples, were ground in a knife mill with a $1 \mathrm{~mm}$ sieve and stored for future laboratory analysis. Water was provided ad libitum and the consumption of water was measured daily. Collected samples were submitted to chemical analyses. Dry matter (DM) and crude protein (CP) were evaluated using methods 967.03 and 981.10 , respectively, in accordance with methods provided within Official Methods of Analysis [OMA] (2016). $\mathrm{NDF}$, acid detergent fibre (ADF), and lignin (LIG) content was assessed with an Ankom device using the sequential method (Ankom, 2020).

Ingestive behaviour was assessed throughout two, non-consicutive 24-hour periods, and animals were observed for five-min intervals to assess the following behavioural variables: resting (REST), rumination (RUM), intake (INT) and chewing (CHEW) (Fischer, Deswysen, Despres, Dutilleul, \& Lobato, 1998). Observations were carried out by trained observers, using a relay system and observers were strategically positioned so as not to disturb the animals. Observations began at 8:00 am and ended at the same time the following day. Animal activity was assessed to estimate min activity per day, and assumed that in the five minutes following each observation, animal activity remained constant, in accordance with previously published methods (Fischer, Dutilleul, Deswysen, Dèspres, \& Lobato, 2000a,b). Total chewing time (TChewT) was determined by determining the sum of time spent on feeding and ruminating. Nocturnal observations of animals were performed using artificial lighting from incandescent lamps. The shed was artificiallhy lit at night throughout the experimental period.

To evaluate the particle size of each diet containing different percentages of $\operatorname{BMB}(0 ; 7.5$; 
15 and 22.5\%), the Penn State Particle Size (PSPS) particle separator was used. The separator contained four sieves in which four different particle sizes were separated, as follows: $>19.00 \mathrm{~mm}$, between $19.00 \mathrm{~mm}$ and $8.00 \mathrm{~mm}$, between $8.00 \mathrm{~mm}$ and $1.18 \mathrm{~mm}$, and particles $<1.18 \mathrm{~mm}$. The PSPS was used in accordance with methodology described by Heinrichs and Jones (2016). Five back and forth movements were performed at each of the sieve positions, and then the set was rotated $90^{\circ}$. This was repeated eight times, so a total of 40 movement were performed. Afterward, the mass of particles retained in each of the sieves was weighed using a digital scale to determine PSPS.

Factors influencing ingestive behaviour were obtained by assessing the following relationships:

$$
\begin{aligned}
\mathrm{EDMI} & =\mathrm{DMI} / \mathrm{TSF}(1), \\
\mathrm{ENDFI} & =\mathrm{NDFI} / \mathrm{TSF}(2),
\end{aligned}
$$

where:

DMI $(\mathrm{g})$ indicates daily dry matter consumption, NDFI $(\mathrm{g})$ indicates daily consumption of NDF and TSF indicated time spent feeding daily. EDMI ( $\mathrm{g}$ DMI $h^{-1}$ ) and ENDFI (g NDFI h${ }^{-1}$ ) were used to determine feed efficiency. Further, the folowwing equations 3 and 4 descirbe efficiency of rumination and time spent ruminating, respectively:

$$
\text { ERUM= DMI/TRU, (3) }
$$

$$
\text { ERUMNDF }=\text { CFDN/TRU, (4) }
$$

where:

ERUM is g ruminated DM $\mathrm{h}^{-1}$ and ERUMNDF (efficiency of rumination) is $\mathrm{g}$ ruminated NDF $\mathrm{h}^{-1}$, and TRU ( $\mathrm{h} \mathrm{day}^{-1}$ ) indicates the duration of rumination. Total chewing time was determined with the following equation:

$$
\mathrm{TSChew}=\mathrm{TSF}+\mathrm{TRU},(5)
$$

where:

TSChew indicates time spent chewing.
The experimental design used was completely randomized, and the effects of all four experimental treatments were assessed using five replicates. Statistical analyses were performed using GLM (General Linear Models) procedures and SAS (Statistical Analysis System) (Statistical Analysis System Institute [SAS] (2015) software, using the following statistical model:

$$
\mathrm{Y}_{\mathrm{ij}}=\boldsymbol{\mu}+\underset{\mathrm{j}}{\mathrm{H}}+\underset{\mathrm{ij}}{\mathrm{e}},(6)
$$

Where Yij indicates observations of repetition $i$ and treatment $\mathrm{j}, \mu$ indicates the average, $\mathrm{Hj}$ represents the effect of treatment $\mathrm{j}(\mathrm{j}=1,2,3$, or 4$)$, and eij indicates random error associated with an observation.

The normality (Shapiro \& Wilk, 1965) and homoscedasticity (Cochran, 1941) of data were assessed. Normal variables and those with homogeneous variances were submitted to linear regression analysis, and when linear, quadratic effects were observed, no adjustment was made to the model. Type I error was assessed using the F test, and values of $\mathrm{P}$ greater or equal to 0.05 were considered significant.

\section{Results and Discussion}

Significant differences were observed for all variables analyzed (Table 3). A linear increase was observed for DMI, expressed in $\mathrm{g} \mathrm{day}^{-1}$ animal $^{-1}, \%$ of live weight $(\% \mathrm{BW}), \mathrm{g} \mathrm{kg}^{-0.75}$, as a function of I-BMB. Some factors may have influenced the enhanced level of consumption observed. Therefore, it was inferred that factors linked to I-BMB, such as particle size and fibre quantity, may have influenced the result. It is important to note that increases in I-BMB were accompanied by a reductions in Napier grass silage (Table 2), a food that has a larger particle size than $\mathrm{BMB}$, and therefore, produces a significant physical effect on rumen filling, which could justify observed increases in DMI. 
Table 3

Voluntary consumption of fractions dry matter (DMI), crude protein (CPI), neutral detergent fibre (NDFI) and acid detergent fibre (ADFI)

\begin{tabular}{|c|c|c|c|c|c|c|c|}
\hline \multirow{2}{*}{ Parameter } & \multicolumn{4}{|c|}{ Trataments } & \multicolumn{3}{|c|}{$P$} \\
\hline & $0 \%$ & $7,5 \%$ & $15 \%$ & $22,5 \%$ & LE & QE & LMA \\
\hline \multicolumn{8}{|c|}{ Consumption $\left(\mathrm{g} \mathrm{day}^{-1}\right.$ animal $\left.^{-1}\right)$} \\
\hline \multirow{2}{*}{ DMI } & 895,84 & 1075,51 & 1203,92 & 1224,61 & \multirow{2}{*}{$<0,001$} & \multirow{2}{*}{0,234} & \multirow{2}{*}{0,432} \\
\hline & $\hat{\mathrm{Y}}=$ & $92208+1$ & $248 \mathrm{X}\left(\mathrm{R}^{2}\right.$ & $55 \%)$ & & & \\
\hline \multirow{2}{*}{ CPI } & 129,87 & 168,54 & 203,53 & 227,47 & \multirow{2}{*}{$<0,001$} & \multirow{2}{*}{0,379} & \multirow{2}{*}{0,105} \\
\hline & & $37,661+3$ & $\mathrm{X}\left(\mathrm{R}^{2}=87\right.$ & & & & \\
\hline \multirow{2}{*}{ NDFI } & 221,53 & 228,17 & 303,20 & 318,77 & \multirow{2}{*}{$<0,011$} & \multirow{2}{*}{0,399} & \multirow{2}{*}{0,356} \\
\hline & & $12,910+4$ & $\mathrm{X}\left(\mathrm{R}^{2}=88\right.$ & & & & \\
\hline \multirow{2}{*}{ ADFI } & 102,9 & 137,35 & 153,62 & 174,23 & \multirow{2}{*}{0,022} & \multirow{2}{*}{0,136} & \multirow{2}{*}{0,570} \\
\hline & & $07,529+3$ & $\mathrm{X}\left(\mathrm{R}^{2}=97\right.$ & & & & \\
\hline \multicolumn{8}{|c|}{ Percentage of live weight (\% BW) } \\
\hline \multirow{2}{*}{ DMI } & 3,81 & 4,44 & 4,59 & 4,99 & \multirow{2}{*}{0,002} & \multirow{2}{*}{0,246} & \multirow{2}{*}{0,176} \\
\hline & & $3,910+0$ & $\left(\mathrm{R}^{2}=94\right.$, & & & & \\
\hline \multirow{2}{*}{ CPI } & 0,53 & 0,75 & 0,78 & 0,87 & \multirow{2}{*}{0,021} & \multirow{2}{*}{0,263} & \multirow{2}{*}{0,519} \\
\hline & & $0,577+0$ & $\left(\mathrm{R}^{2}=88\right.$, & & & & \\
\hline \multirow{2}{*}{ NDFI } & 0,947 & 0,951 & 1,164 & 1,301 & \multirow{2}{*}{0,011} & 0244 & 0451 \\
\hline & & $8,998+0$ & $\left(\mathrm{R}^{2}=90\right.$, & & & 0,244 & 0,451 \\
\hline$\triangle D F I$ & 0,440 & 0,569 & 0,592 & 0,711 & $<0001$ & (1020 & 0107 \\
\hline ADFI & & $4,531+0$ & $\left(\mathrm{R}^{2}=94\right.$, & & $<0,001$ & 0,210 & 0,191 \\
\hline Metabolic & $\left.g^{-0.75}\right)$ & & & & & & \\
\hline DMI & 83,81 & 98,44 & 103,79 & 111,19 & 012 & $048 ?$ & 0141 \\
\hline DMI & & $6,189+1$ & $\left(R^{2}=95\right.$ & & 0,012 & 0,482 & 0,141 \\
\hline CPI & 0,542 & 1,02 & 0,92 & 0,92 & $<0001$ & 0235 & 0.630 \\
\hline CPI & & $2,314+0$ & $\left(\mathrm{R}^{2}=99\right.$ & & $<0,001$ & 0,235 & 0,639 \\
\hline NDFI & 20,783 & 21,018 & 26,262 & 28,952 & 0001 & $0>30$ & 0363 \\
\hline NDFI & & $9,791+0$ & $\left(\mathrm{R}^{2}=91\right.$ & & $<0,001$ & 0,230 & 0,363 \\
\hline$\triangle \mathrm{DFI}$ & 9,67 & 12,58 & 13,34 & 15,83 & & 0477 & 0512 \\
\hline ADFI & & $9,972+0$ & $\left(\mathrm{R}^{2}=95\right.$, & & $<0,001$ & 0,477 & 0,512 \\
\hline
\end{tabular}

Abbreviations: ${ }^{\mathrm{NS}}$, not significant; CMS, dry matter consumption; CPB, consumption of crude protein; CFDN, consumption of neutral detergent fibre; CFDA, consumption of fibre in acid detergent; $p$, probability of type I error; LE, linear effect; QE, quadratic effect; LMA, lack of model adjustment.

Food consumption by ruminants is regulated by both physical and metabolic factors (Forbes, 2005; Detmann, Gionbelli, \& Huhtanen, 2014). Mammals in general, and ruminants particularly, have been determined to show preferences for foods in which the combined protein and energy content maximizes animal productivity (Ellis, Li, Yang, \& Cheng,
2000; Forbes, 2007). This has the potential to either total dry matter consumption.

In the present study, increased DMI was observed in animals I-BMB. The particle size of diets provided was very small (Table 4 ), which suggested that there was an increased rate of passage, and thus, 
a need for enhanced levels of food intake to meet the nutritional needs of animals to facilitate weight gain and production was observed. In animals fed I-FMB, DM injestion was considered adequate when compared with recommendations of the NRC (2007), which stated that $1.0 \mathrm{~kg}$ of DM day ${ }^{-1}$ per 22 $\mathrm{kg} \mathrm{BW}$. This was similar to findings of Veras et al. (2005), who determined an average of $1.150 \mathrm{~kg}^{-}$day $^{-}$ ${ }^{1}$ was consumed by sheep within the same weight range that were fed diets containing palm bran instead of corn. The mean DMI value for sheep of the present study was determined to be $1.1 \mathrm{~kg} \mathrm{day}^{-1}$.

Table 4

Percentage particle size distribution for diets containing different levels of babassu mesocarp bran (BMB)

\begin{tabular}{ccccc}
\hline Trataments $(\%)$ & $>19 \mathrm{~mm}(\%)$ & $19<8 \mathrm{~mm}(\%)$ & $8<1,18 \mathrm{~mm}(\%)$ & $<1,18 \mathrm{~mm}(\%)$ \\
\hline 0,0 & 2,65 & 8,95 & 63,40 & 25,00 \\
7,5 & 1,50 & 6,80 & 65,57 & 26,13 \\
15,0 & 1,25 & 5,60 & 69,90 & 23,25 \\
22,5 & 1,55 & 4,45 & 73,39 & 20,61 \\
\hline
\end{tabular}

mm, Millimetre.

Average DMI was 83.81, 98.44, 103.79 and $111.19 \mathrm{~g} \mathrm{~kg}^{-0.75}$ for animals fed $0,7.5,15$ and $22.5 \%$ I-BMB diets, respectively. It is currently known that two factors that determine consumption levels, are energy intake by the animal and NDF concentration within the diet. Of these, NDF concentration is considered limiting due to its slow rates of degradation and passage through the rumen, when compared with non-fibrous carbohydrates (NFCs).

However, by-products of BMB possess fine granulometry and, therefore, result in increased proportions of small particles within the diet as I-BMB increases (Table 4). Other factors, along with rumen filling may affect the regulation of consumption, since passage rates of particles of similar sizes may increase, a circumstance that would reduce the satiety as a result of rumen filling (Lima et al., 2012). However, the thinner the diet, the lower the expected volume of rumen occupation and degree rumen filling, which are factors that have also increased levels of consumption (Mertens, 1997). However, increased DMI values observed here may also be due to the low energy availability of BMB, which causes the animal to ingest increased quantities of food in order to satisfy its appetite.
Sheep are selective animals and, most likely, this positively influenced levels of BMB ingested. In work reported by Dado and Allen (1995), physical diet forms can alter durations of both rumination and chewing. Despite its fine granulometry, inclusion of BMB did not significantly alter absolute durations of rumination, ingestion of food and chewing. Thus, the granulometry of diets containing BMB tended to have a very small particle sizes, and more than $85 \%$ of the diets assessed had particle sizes of less than $8 \mathrm{~mm}$.

Particles smaller than $1.18 \mathrm{~mm}$ may escape from the rumen by passing through the reticulumomasal orifice. These small particles do not require rumination or degradation by ruminal microorganisms. In this context, it is clear (Table 4) that a large percentage of particles smaller than 1.18 $\mathrm{mm}$ are able to escape the rumen-reticulum with digesta, without undergoing any type of mechanical or microbiologically mediated particle breakdown processes (Poppi, Norton, Minson, \& Hendricksen, 1980). In accordance with this idea, the permanence of food within the rumen was reduced.

Particles between $8<1.18 \mathrm{~mm}$ accounted for approximately $70 \%$ of the particles of the diet. 
According to Allen (1997) this proportion may influence rumination. Proportion of BMB provided within the diets of animals significantly affected (p $<0.05$ ) CPI (g of CP day ${ }^{-1}$ animal $^{-1}$ ), \% BW and $\mathrm{g} \mathrm{kg}^{-0.75}$, and levels increased in a linear manner as I-BMB increased. The treatments that included $\mathrm{BMB}$ had close to 174 and $196 \mathrm{~g} \mathrm{CP}$ day $^{-1}$ animal $^{-1}$ for 20 and $30 \mathrm{~kg}$ lambs, respectively, which are values recommended by the NRC (2007). The mean CPI value determined was $182.38 \mathrm{~g} \mathrm{CP}_{\text {day }^{-1}}$ animal $^{-1}$ (Table 3).

This result is in accordance with findings of Urano et al. (2006), who obtained an average value of 183.7 CP day ${ }^{-1}$ animal $^{-1}$ in Santa Inês lambs fed a soybean diet. It can be inferred increased CPI may have been linked the high levels of CP present in the fibrous fraction of $\mathrm{BMB}$, which was occurred as nitrogen insoluble in neutral detergent (NIND) and nitrogen insoluble in acid detergent (NIAD) (Table 1). Thus, animals consume increased levels of CP, but they cannot be used. In this context, animals tended to consume increased levels of CP in an attempt to overcome rumen $\mathrm{N}$ deficits, which, together with energy, governs rumen fermentation dynamics. Thus, trends observed regarding CPI consumption tended to mirror those of other nutrients consumed by lambs. When lambs they were fed increasing levels of BMB, diets were isoproteic (Table 2). Further, increased DMI naturally increased levels of CPI (Table 3), and caused animals to consume more food to meet energy and protein requirements.

Table 3 includes data regarding NDFI and ADFI, \% BW, and DMI, and significant differences between animals fed varying percentages of BMB significantly differed $(p<0.05)$. Therefore, it can be inferred that the high concentrations of fibre in feed containing high levels of BMB (Table 1) may have been the reason that the animals consumed increased volumes of feed. Mertens (1997) suggested that consumption by filling was correlated to levels of NDF within feed and proposed that physical mechanisms allowed for a maximal average value of $1.2 \% \mathrm{BW}$ was possible in cattle. However, more recent studies (Freitas et al., 2008; Ramos et al., 2013) involving sheep breeds produced in Brazil and with different sources of fibre have reported levels of consumption of NDF that have ranged from $1.25 \% \mathrm{BW}$ in diets with sugarcane to $0.87 \%$ BW for diets composed of Tifton hay. The NDF consumption values reported these authors for feed containing levels that corresponded to the $0.0,7.5$, 15.0 BMB of the present study $(0.947 ; 0.951$ and $1.164 \%$ BW in NDF) were similar, however data obtained when at the highest level of I-BMB in this study was greater findings previously reported $(1.301 \% \mathrm{BW})$. This indicates that despite the fibrous nature of BMB (Table 1), it does not cause rumen filling like other more traditional fibrous foods.

BMB does contain high levels of NDF $(60.2 \%)$ (Table 1), and the feed is characterized as fibrous, however, NDF level is not the sole determinant of rumen filling. Some foods may contain high levels of NDF, but small particle size may prevent rumen filling, as is likely the case here. In the present study, NDF consumption by sheep ranged from 221.53 to $318.77 \mathrm{~g} \mathrm{day}^{-1}$ animal $^{-1}$, values that are well below those 442.79 to $561.22 \mathrm{~g} \mathrm{day}^{-1}$ animal $^{-1}$ levels determined by Rodrigues et al. (2003) using cashew nut bran, another source of starch with similar fibrous fraction.

In Table 5, data indicates that no significant differences $(p>0.05)$ in water consumption were observed when consumption of free water was assessed as a function of live weight $\left(\mathrm{H}_{2} \mathrm{O}\right.$ I (L day ${ }^{-}$ $\left.{ }^{1}\right)$ ), metabolic weight $\left(\mathrm{H}_{2} \mathrm{O} \mathrm{I}\left(\mathrm{L} \mathrm{MW}^{-0.75}\right)\right)$, or dry matter intake $\left(\mathrm{H}_{2} \mathrm{O} \mathrm{I}\left(\mathrm{L} \mathrm{DMI}^{-1}\right)\right)$. 
Table 5

Average water consumption of lambs fed diets containing different inclusion levels of babassu mesocarp bran (I-FMB)

\begin{tabular}{|c|c|c|c|c|c|c|c|}
\hline \multirow{2}{*}{ Parameter } & \multicolumn{4}{|c|}{ Trataments } & \multicolumn{3}{|c|}{$p$} \\
\hline & $0,0 \%$ & $7,5 \%$ & $15,0 \%$ & $22,5 \%$ & LE & $\mathrm{QE}$ & LMA \\
\hline \multirow{2}{*}{$\mathrm{H}_{2} \mathrm{O}$ I $\left(\mathrm{L} \mathrm{day}^{-1}\right) *$} & 1,43 & 1,31 & 0,95 & 1,27 & 0345 & 0234 & 0.432 \\
\hline & \multicolumn{4}{|c|}{$\hat{\mathrm{Y}}=\mathrm{NS}$} & ניכנ, & 0,234 & $0,4 J 2$ \\
\hline \multirow{2}{*}{$\mathrm{H}_{2} \mathrm{O} \mathrm{I}\left(\mathrm{L} \mathrm{BW}^{-1}\right) * *$} & 5,64 & 5,41 & 3,83 & 5,17 & 023 & 0216 & 0176 \\
\hline & \multicolumn{4}{|c|}{$\hat{\mathrm{Y}}=\mathrm{NS}$} & & & \\
\hline \multirow{2}{*}{$\mathrm{H}_{2} \mathrm{O}$ I $\left(\mathrm{L} \mathrm{BW}^{-0,75}\right) * * *$} & 126,13 & 120,05 & 85,61 & 115,32 & 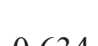 & & \\
\hline & \multicolumn{4}{|c|}{$\hat{\mathrm{Y}}=\mathrm{NS}$} & 0,034 & 0,402 & 0,141 \\
\hline \multirow{2}{*}{$\mathrm{H}_{2} \mathrm{O} \mathrm{I}\left(\mathrm{L} \mathrm{DMI}^{-1}\right)^{* * * *}$} & 1,48 & 1,24 & 0,79 & 1,03 & 35 & ? & 12 \\
\hline & \multicolumn{4}{|c|}{$\hat{\mathrm{Y}}=\mathrm{NS}$} & 0,435 & 0,352 & 0,093 \\
\hline \multirow{2}{*}{$\mathrm{H}_{2} \mathrm{O}-\mathrm{D} * * * * *$} & 369,71 & 289,04 & 240,68 & 167,90 & 0003 & 0370 & 0105 \\
\hline & \multicolumn{4}{|c|}{$\hat{\mathrm{Y}}=0,364-0,0086 \mathrm{X}\left(\mathrm{R}^{2}=99,22 \%\right)$} & o, & & 0,105 \\
\hline
\end{tabular}

* (L day-1 animal-1); ** (\% PV); *** (gH2O kgPV-0.75); **** (mL kg-1); ***** (mL kg-1)

Abbreviations: ${ }^{\mathrm{NS}}$, not significant; $\mathrm{H}_{2} \mathrm{O}$ I $\left(\mathrm{L} \mathrm{day}^{-1}\right)$, Free water consumption; $\mathrm{H} 2 \mathrm{O}$ I $\left(\mathrm{L} \mathrm{BW}^{-1}\right)$, free water consumption as a percentage of live weight; H2O I ( $\left.\mathrm{L} \mathrm{PV}^{-0.75}\right)$, free water consumption as a function of metabolic weight; $\mathrm{H}_{2} \mathrm{O}-\mathrm{D}$, water present in the diet; $\mathrm{p}$, probability of type I error; LE, linear effect; QE, quadratic effect; LMA, lack of model adjustment.

According to Araújo, Voltolini, Chizzotti, Turco and Carvalho (2010), water consumption depends on three factors. The first is level of diet consumption. Here, each diet was isonitrogenated, isoenergetic and contained similar levels of NDF. The second factor that influences water consumption is the relationship between $\mathrm{H}_{2} \mathrm{O}$ I and DMI, which did not significantly differ here (Table 5). Finally, the third aspect that may influence consumption is thermal comfort. Since all animals were housed in a shed that was covered with babassu straw, which improved thermal comfort and protected animals from experiencing extreme temperatures, like other natural straws commonly used as roofing materials (Lavor, Fernandes, \& Sousa, 2008).

Data within Table 5 reveals that water present in the diet $\left(\mathrm{H}_{2} \mathrm{O}-\mathrm{D}\right)$ decreases linearly with increased I-BMB, which is due to the high dry matter content of BMB (Table 1). It was expected that $\mathrm{H}_{2} \mathrm{O}$ I would increase in animals fed increasing levels of BMB, because water present in food would decrease. Therefore the reduced level of water in the diet was expected to result in enhanced water consumption by animals. The literature reports that water consumption should be 1.5 to 3.0 times dry matter consumption (Marino, 2005). We can verify that animals in this study had water consumption values that were lower recommended.

No signfiicant differences were observed ( $\mathrm{p}$ $>0.05$ ) regarding levles of leisure, ingestion, rumination and chewing times in animals fed different diets. Also, ingestion times observed for animals fed different diets did not differ according to DMI, NDFI and NDAI (Table 6). However, in animals fed different diets, rumination due to DMI, NDFI and NDAI (Table 6) did significantly differ. This may be a result of reduced levles effective fibre present within diets containing greater percentages of BMB. However, fibrous by-products with small particle sizes are stimulators of rumination, since they form thick rumen supernatant, and thereby stimulate rumination, which can enhance rumination efficiency (Lima et al., 2012). 
Table 6

Mean times spent ingesting, ruminating and chewing as a function of dry matter (CMS), neutral detergent insoluble fibre (CFDN), acid detergent insoluble fibre (CFDA) consumption and leisure time in lambs fed increasing levels of babassu mesocarp bran (FMB)

\begin{tabular}{|c|c|c|c|c|c|c|c|}
\hline \multirow{2}{*}{ Activity } & \multicolumn{4}{|c|}{ Trataments } & \multicolumn{3}{|c|}{$p$} \\
\hline & $0 \%$ & $7,5 \%$ & $15 \%$ & $22,5 \%$ & LE & $\mathrm{QE}$ & LMA \\
\hline \multirow{2}{*}{ Resting * } & 57,47 & 62,39 & 56,09 & 59,76 & 0063 & 0817 & 0076 \\
\hline & \multicolumn{4}{|c|}{$\hat{\mathrm{Y}}=\mathrm{NS}$} & 0,903 & 0,017 & \\
\hline \multirow[t]{2}{*}{ Int * } & 20,75 & 17,40 & 19,47 & 16,76 & 0,746 & 0.237 & 0,023 \\
\hline & \multicolumn{4}{|c|}{$\hat{Y}=N S$} & & & \\
\hline \multirow{2}{*}{ Rum * } & 15,36 & 12,99 & 15,84 & 15,60 & 0635 & 0726 & 0012 \\
\hline & \multicolumn{4}{|c|}{$\hat{\mathrm{Y}}=\mathrm{NS}$} & & & \\
\hline \multirow{2}{*}{ Chew * } & 6,42 & 7,22 & 8,61 & 7,88 & 0473 & 0236 & 0120 \\
\hline & \multicolumn{4}{|c|}{$\hat{\mathrm{Y}}=\mathrm{NS}$} & $0,4 / 3$ & 0,236 & 0,129 \\
\hline \multirow{2}{*}{$\mathrm{Int} / \mathrm{DMI} * *$} & 3,726 & 4,976 & 4,418 & 4,638 & 0381 & 0258 & 0073 \\
\hline & \multicolumn{4}{|c|}{$\hat{\mathrm{Y}}=\mathrm{NS}$} & & & \\
\hline \multirow{2}{*}{ Int/NDFI ** } & 0,926 & 1,048 & 1,106 & 1,206 & 0120 & 0606 & 0030 \\
\hline & \multicolumn{4}{|c|}{$\hat{\mathrm{Y}}=\mathrm{NS}$} & 0,129 & 0,000 & 0,039 \\
\hline \multirow{2}{*}{$\operatorname{Int} / \mathrm{ADFI} * *$} & 0,432 & 0,634 & 0,566 & 0,658 & 0053 & 0198 & 0101 \\
\hline & \multicolumn{4}{|c|}{$\hat{\mathrm{Y}}=\mathrm{NS}$} & & & \\
\hline \multirow{2}{*}{ Rum/DMI ** } & 2,758 & 3,714 & 3,594 & 4,318 & 0026 & 0350 & 0497 \\
\hline & \multicolumn{4}{|c|}{$\hat{\mathrm{Y}}=2,914+0,061 \mathrm{X}\left(\mathrm{R}^{2}=92,34 \%\right)$} & $0,0<0$ & 0,כנסט & 0,491 \\
\hline \multirow{2}{*}{ Rum/NDFI $* * 2$} & 0,674 & 0,774 & 0,908 & 1,122 & 0.017 & 0647 & 0612 \\
\hline & \multicolumn{4}{|c|}{$\hat{\mathrm{Y}}=0,648+0,019 \mathrm{X}\left(\mathrm{R}^{2}=88,32 \%\right)$} & & & \\
\hline \multirow{2}{*}{ Rum/ADFI $* * 3$} & 0,310 & 0,468 & 0,462 & 0,612 & 0004 & 0119 & 0341 \\
\hline & \multicolumn{4}{|c|}{${ }^{3} \hat{\mathrm{Y}}=0,329+0,012 \mathrm{X}\left(\mathrm{R}^{2}=93,72 \%\right)$} & 0,004 & 0,119 & 0,341 \\
\hline \multirow{2}{*}{ Chew/DMI $* * 4$} & 1,152 & 2,066 & 1,954 & 2,182 & 0,034 & 0156 & 0.432 \\
\hline & \multicolumn{4}{|c|}{$\hat{\mathrm{Y}}=1,649+0,025 \mathrm{X}\left(\mathrm{R}^{2}=90,23 \%\right)$} & & & \\
\hline \multirow{2}{*}{ Chew/NDFI $* * 5$} & 0,376 & 0,432 & 0,494 & 0,568 & \multirow{2}{*}{0,002} & \multirow{2}{*}{0,441} & \multirow{2}{*}{0,348} \\
\hline & & $\hat{\mathrm{Y}}=0,371+0$ & $\mathrm{R}^{2}=87$ & & & & \\
\hline \multirow{2}{*}{ Chew/ADFI **6 } & 0,174 & 0,264 & 0,250 & 0,308 & \multirow{2}{*}{0,006} & 0,083 & 0,546 \\
\hline & & $\hat{\mathrm{Y}}=0,189+0$ & $\mathrm{R}^{2}=95$ & & & $0,00 \mathrm{~J}$ & \\
\hline
\end{tabular}

* $(\%$ of TT); $* *$ (min g-1 day- 1$)$.

Abbreviations: Ns, not significant; p, probability of type I error; Int, intake; Rum, rumination; Chew, Chewing; DMI, dry matter intake; NDFI, consumption of insoluble fibre in neutral detergent; ADFI, consumption of insoluble fibre in acid detergent; min, minutes; LE, linear effect; QE, quadratic effect; LMA, lack of model adjustment.

Rumination is an important sheep activity, and the behaviour is influenced by diet and type of management, and seems to be proportional to the cell wall content of food (Van Soest, 1994). Therefore, another factor that may have affected rumination in animals of the present study may have been the granulomtrey of BMB, which was very low $(<8 \mathrm{~mm})$, for more than $85 \%$ of the total (Table $4)$. Thus, there may be selection by animals to seek foods with high levels of fibre to maintain rumen functioning. However, there have been no studies published that have investgated this type of animal behaviour. 
Significant differences $(p<0.05)$ between chewing times offor chewing times for each $1 \%$ of I-BMB were observed for DMI, NDFI and ADFI $\left(0.060,0.019\right.$ and $0.011 \mathrm{~min}^{-1}$ day $^{-1}$, respectively) (Table 6). This increase can be explained by the bromatological characteristics of $\mathrm{BMB}$, which reduce levles of effective fibre content within the diet, due to the granulometry changes that occurr as a result of I-BMB (Table 4). In the present work, I-BMB reduced efficiency of rumination and chewing time, which indicated that animals fed greater I-BMB spent more time ruminating and chewing food. However, this did not reduce ingestion efficiency.

\section{Conclusion}

The inclusion of BMB in the diet of lambs increases voluntary consumption in sheep and negatively influences rumination and chewing efficiency, without impairing ingestion efficiency. Therefore, inclusion of up to $22.5 \%$ BMB within balanced diets is possible.

\section{Acknowledgement}

This work was carried out with the financial assistance of the Coordination for the Improvement of Higher Education Personnel (CAPES), the National Council for Scientific and Technological Development (CNPq), and the Research Productivity Scholarship Programme of the Federal University of Tocantins (UFT).

\section{References}

Abdalla, A. L., Silva, J. C. da, Fo., Godoi, A. R. de, Carmo, C. de A., \& Eduardo, J. L. de P. (2008). Utilização de subprodutos da indústria de biodiesel na alimentação de ruminantes. Revista Brasileira de Zootecnia, 37(supl. esp.), 260-268. doi: 10.1590/ S1516-35982008001300030

Allen, M. S. (1997). Relationship between fermentation acid production in the rumen and the requirement for physically effective fiber. Journal of Dairy Science, 80(7), 1447-1462. doi: $10.3168 /$ jds.S0022-0302 (97) $76074-0$

Ankom (2020). Neutral detergent fiber in feeds - filter bag technique (for A200 and A200I). Retrieved from https://www.ankom.com/sites/default/files/ document-files/Method_6_NDF_A200.pdf

Araújo, G. G. L. de, Voltolini, T. V., Chizzotti, M. L., Turco, S. H. N., \& Carvalho, F. F. R. de. (2010). Water and small ruminant production. Revista Brasileira de Zootecnia, 39(supl. esp.), 326-336. doi: 10. 1590/S1516-35982010001300036

Cardoso, A. R., Pires, C. C., Carvalho, S., Galvani, D. B., Jochims, F., Hastenpflug, M., \& Wommer, T. P. (2006). Consumo de nutrientes e desempenho de cordeiros alimentados com dietas que contem diferentes níveis de fibra em detergente neutro. Ciência Rural, 36(1), 215-221. doi: 10.1590/S010384782006000100033

Cochran, W. G. (1941). The distribution of the largest of a set of estimated variances as a fraction of their total. Annals of Human Genetics, 11(1), 47-52. doi: 10.1111/j.1469-1809.1941.tb02271

Dado, R. G., \& Allen, M. S. (1995). Intake limitations, feeding behavior, and rumen function of cows challenged with rumen fill from dietary fiber or inert bulk. Journal of Dairy Science, 78(1), 118-133. doi: 10.3168/jds.S0022-0302(95) 76622-X

Detmann, E., Gionbelli, M. P., \& Huhtanen, P. (2014). A meta-analytical evaluation of the regulation of voluntary intake in cattle fed tropical forage-based diets. Journal of Animal Science, 92(10), 4632-4641. doi: $10.2527 /$ jas.2014-7717

Ellis, E. C., Li, R. G., Yang, L. Z., \& Cheng, X. (2000). Changes in village-scale nitrogen storage in China's Tai Lake Region. Ecological Applicnrion, 10(4), 1074-1089. doi: $10.2307 / 2641018$

Fischer, V., Deswysen, A. G., Despres, L., Dutilleul, P., \& Lobato, J. F. P. (1998). Padrões nictemerais do comportamento ingestivo de ovinos. Revista Brasileira de Zootecnia, 27(1), 362-369. doi: 10.1590/ S0103-84782006000100033

Fischer, V., Dutilleul, P., Deswysen, A. G., Dèspres, L., \& Lobato, J. F. P. (2000a). Aplicação de probabilidades de transição de estado dependentes do tempo na análise quantitativa do comportamento ingestivo de ovinos - parte I. Revista Brasileira de Zootecnia, 29(6), 1811-1820. doi: 10.1590/S151635982000000600030 
Fischer, V., Dutilleul, P., Deswysen, A. G., Dèspres, L., \& Lobato, J. F. P. (2000b). Aplicação de probabilidades de transição de estado dependentes do tempo na análise quantitativa do comportamento ingestivo de ovinos - parte II. Revista Brasileira de Zootecnia, 29(6), 1821-1831. doi: 10.1590/S151635982000000600031

Forbes, J. M. (2007). Voluntary food intake and diet selection in farm animals (2nd ed.). Cambridge: University Press.

Forbes, J. M. (2005). Voluntary feed intake and diet selection. In, J. Dijkstra, J. M. Forbes, \& J. France (Eds.), Quantitative aspects of ruminant digestion and metabolism (pp. 607-626). Edition Cambridge, University Press.

Freitas, A. W. de P., Rocha, F. C., Zonta, A., Fagundes, J. L., Fonseca, R. da, Zonta, M. C. de M., \& Macedo, F. L. (2008). Consumo de nutrientes e desempenho de ovinos alimentados com dietas à base de canade-açúcar hidrolisada. Pesquisa Agropecuária Brasileira, 43(11), 1569-1574. doi: 10.1590/ S0100204X2008001100016

Heinrichs, P. J., \& Jones, C. M. (2016). The Forage and TMR particle separator was designed to help in determining the correct forage particle length needed to improve ruminant nutrition. Cooperative Extension, 1-16. Retrieved from https://extension. psu.edu/penn-state-particle-separator

Lavor, C. T. B., Fernandes, A. A. O., \& Sousa, F. M. de. (2008) Efeito de materiais isolantes térmicos em aviários no desempenho de frangos de corte. Revista Ciência Agronômica, 39(2), 308-316. Recuperado de http://www.redalyc.org/src/inicio/ArtPdfRed .jsp?iCve $=195317754019$

Lima, M. L. M., Castro, F. G. F., Amaral, A. das G., Carvalho, E. R. de, Nussio, L. G., \& Mattos, W. R. S. (2012). Comparação da fibra em detergente neutro de forragens: desempenho, digestibilidade e parâmetros ruminais. Ciência Animal Brasileira, 13(4), 450459. doi: $10.5216 /$ cab.v13i4.19468

Marino, C. T. (2005). Água na produção animal. (Informe Técnico, 2005). Campo Grande: Macal Nutrição Animal.

Mertens, D. R. (1997). Creating a system for meeting the fiber requirements of dairy cows. Journal of Dairy Science, 80(7), 1463-1481. doi: 10.3168/jds.S00220302(97)76075-2
Miotto, F. R. C., Restle, J., Neiva, J. N. M., Resende, P. L. de P., Lage, M. E., Prado, C. S.,... Araújo, V. L. (2012). Farelo de mesocarpo de babaçu (Orbygnia sp.) na terminação de bovinos: composição física da carcaça e qualidade da carne. Ciência Rural, 42(7), 12711277. doi: 10.1590/S0103-84782012005000041

National Research Council (2007). Nutrient requeriments of small ruminants. Washington, D.C.: National Academic Press.

Official Methods of Analysis (2016): Association official analytical chemists (20nd ed. rev.). Gaithersburg, USA: AOAC Internacional.

Poppi, D. P., Norton, B. W., Minson, D. J., \& Hendricksen, R. E. (1980). The validity of the critical size theory for particles leaving the rumen. Journal of Agriculture Science, 94(2), 275-280. doi: 10.1017/ S0021859600028859

Porro, R. (2019). A economia invisível do babaçu e sua importância para meios de vida em comunidades agroextrativistas. Boletim do Museu Paraense Emílio Goeldi. Ciências Humanas, 14(1), 169-188. doi: 10.1590/1981.8122201900 0100011

Ramos, A. O., Ferreira, M. de A., Véras, A. S. C., Costa, S. B. de M., Conceição, M. G. da, Silva, E. C. da,... Souza, A. R. D. L. (2013). Diferentes fontes de fibra em dietas a base de palma forrageira na alimentação de ovinos. Revista Brasileira de Saúde e Produção Animal, 14(4), 648-659. doi: 10.1590/ S151999402013000400005

Rodrigues, M. M., Neiva, J. N. M., Vasconcelos, V. R., Lôbo, R. N. B., Pimentel, J. C. M., \& Moura, A. de A. A. N. (2003). Utilização do farelo de castanha de caju na terminação de ovinos em confinamento. Revista Brasileira de Zootecnia, 32(1), 240-248. doi: 10.1590/S1516-35982003000100030

Shapiro, S. S., \& Wilk, M. B. (1965). An analysis of variance test for normality, (Complete Samples). Biometrika, 52(3/4), 591-611. doi: 10.2307/233370 9

Sousa, L. F., Macedo, G. de L., Jr., Santos, R. P. dos., Silva, A. G. M., \& Borges, I. (2014). Composição bromatológica e cinética da fermentação ruminal de rações contendo resíduos de babaçu. Revista Ciência Agronômica, 45(1), 177-185. doi: 10.1590/S180666902014000100021

Statistical Analysis System Institute (2015). User's guide SAS/STAT: version 9.4. Cary, NC: SAS Institute Inc. 
Urano, F. S., Pires, A. V., Susin, I., Mendes, C. Q., Rodrigues, G. H., Araujo, R. C. de, \& Mattos, W. R. S. (2006). Desempenho e características da carcaça de cordeiros confinados alimentados com grãos de soja. Pesquisa Agropecuária Brasileira, 41(10), 15251530. doi: 10.1590/S0100-204X2006001000010

Van Soest, P. J. (1994). Nutritional ecology of the ruminant. Ithaca: Cornell University Press.
Veras, R. M. L., Ferreira, M. A., Araujo, C. V., Véras, A. S. C., Carvalho, F. F. R. de, Santos, G. R. A. dos.,... Souto Maior, R. J de, Jr. (2005). Substituição do farelo de palma forrageira (Opuntia fícus indica Mill) em dietas de ovinos em crescimento. I. Desempenho. Revista Brasileira de Zootecnia, 34(1), 249-256. doi: 10.1590/S1516-3598200500010002 
